\title{
INFLUENCE OF AIR POLLUTION IN AN URBAN AREA ON HOSPITAL ADMISSIONS FROM ACUTE MYOCARDIAL INFARCTION. ATMOSPHERIC POLLUTION WITH OZONE AND PARTICULATE MATTER IN THE CITY OF VARNA
}

\author{
Dimitrova T. ${ }^{1}$, I. Zlatarov ${ }^{2}$, N. Donchev ${ }^{3}$, A. Penev $^{4}$, E. Tsankova $^{5}$ \\ ${ }^{1}$ Department of Medico-biological sciences, MU Varna, ${ }^{2}$ Department of Hygiene and Disaster \\ Medicine, MU-Varna, ${ }^{3}$ Vascular Surgery, MBAL St. Anna, Varna, ${ }^{4}$ Intensive Cardiology, \\ MBAL St. Marina, Varna, ${ }^{5}$ Medical College, Varna
}

Reviewed by: assoc. prof. St. Popova

\begin{abstract}
The combined action of the atmospheric pollutants as well as their combination with the meteorological parameters leads to alteration of their effects on the heart. Only for the ozone influence is described a relative independence from the rest of the toxic substances in combined action. Aim is to study the possibility for isolated and combined with the other atmospheric pollutants and conditions of work influence of the levels of particulate matter on the frequency of hospital admissions from acute myocardial infarction (AMI). Data obtained from the medical documentation on laboratory and instrumental investigations were assessed of the 585 patients admitted to the Intensive Care Clinic of University Hospital in Varna with a diagnosis of acute myocardial infarction (AMI) in the period from December 2004 to December 2005. Data from the Regional Inspectorate of Environment and Water and the Regional Inspectorate of Protection and Control of Public Health were analysed for the mean daily values of the concentrations of ozone, general particulate matter and fine particulate matter (PM) in atmospheric air. The seasonal subordinations described as well as the variability of the effect in combined models of interaction give reason to assume reciprocal influence of the effects on the coronary blood flow of ozone in its combined influence with the other atmospheric pollutants, as well as in its combination with the various meteorological parameters, and from there indirectly with the sun activity. At the same time those effects are determined also by the diverse individual susceptibility of the exposed persons.
\end{abstract}

Key words: ozone, particulate matter, acute myocardial infarction

The combined action of the atmospheric pollutants as well as their combination with the meteorological parameters leads to alteration of their effects on the heart. Only for the ozone influence is described a relative independence from the rest of the toxic substances in combined action (4).

\section{AIM}

To study the possibility for isolated and combined with the other atmospheric pollutants and conditions of work influence of the levels of particulate matter on the frequency of hospital admissions from acute myocardial infarction (AMI).

\section{SETTING AND METHODS}

Address for correspondence:

T. Dimitrova, Dept. of Medico-biological sciences, Medical University - Varna, 55 Marin Drinov Str., 9002 Varna, Bulgaria e-mail: tvd@mnet.bg
Data obtained from the medical documentation on laboratory and instrumental investigations were assessed: biochemical indicators in serum for overall cholesterol and triglycerides, blood sugar and liver enzymes of the 585 patients admitted to the Intensive Care Clinic of St Marina University Hospital in Varna with a diagnosis of acute myocardial infarction (AMI) in the period from December 2004 to December 2005. Questionnaires were used to investigate 210 of them on cardiovascular risk according to sex, age, family history and occupation. BMI was established using a standard formula. For the same period from October 2004 to December 2005 the relationship between the quality of the atmospheric air and the frequency of hospital admissions form AMI was investigated. Data from the Regional Inspectorate of Environment and Water and the Regional Inspectorate of Protection and Control of Public Health were analysed for the mean daily values of the concentrations of ozone, general particulate matter and fine particulate matter (PM) in atmospheric air. Samples were taken (three manually and one automatically) from four sta- 
tionary points on the territory of the city of Varna as part of a system for monitoring the quality of air. Only hospitalised citizens of Varna were included in the analysis.

For the statistical processing of the data the following methods were applied:

1. method of direct juxtaposition of the levels of the atmospheric pollutants and the frequency of hospital admissions from AMI;

2. method of overlapping of time periods for discovery and mathematical evaluation of the reliability of the connections between the frequency of AMI hospital admissions and the days with increased ozone levels in the atmospheric air;

3. variational, descriptive and correlational analysis.

\section{RESULTS}

As in other investigations, ozone has a typical peak in April and May (15). The lowest levels of pollution are established from October to December. Maximum daily levels are found from late morning to early afternoon hours, the intervals being shorter and levels lower in winter months. Ozone shows the strongest correlation relations with nitrogen oxides. These results that we obtained correspond to the data from a series of investigations examining dispersion and chemical transformation of nitrogen oxide in the ground layers of the atmosphere. The most representative is considered to be the reverse reaction between nitrogen oxide and ozone, $\mathrm{NO}+\mathrm{O}_{3}-\mathrm{NO}_{2}+\mathrm{O}_{2}$. The homogeneity of the chemical reaction, however, is influenced by many factors, for example the turbulence of air masses during airplane movement (8). Since the end of last century there has been observed a causal relationship between the level of the sun activity and the amount of ozone in the air (3). The notion 'sun activity' includes a combination of manifestations and changes of a series of sun phenomena: sunspots, chromospheric eruptions, protuberances, spicules, filaments, rosaries, etc. with an 11-year cycle.

Positive correlation relations with the frequency of hospital admissions from AMI we establish in the spring and summer months when the levels of the pollutant are also higher. In the cold months of the year ozone correlates slightly positively with the frequency of hospital admissions from AMI in persons working overtime ( 0.150 in the same day and 0.134 on the next day) and in persons working under deleterious physical factors of their environment (vibrations and particulate matter 0.136). The effect is established on the next day by the influence of the atmospheric ozone. In drivers this effect continues also on the second day $(0.161+$ 1 day, $0.151+2$ days). The short-term (1 to 3 days) ozone exposure is associated with acute coronary incidents in persons without history of heart disease. That observation is confirmed by investigations in various towns comparing the ozone levels with the frequency of hospital admissions from coronary incidents (7) and cardiovascular mortality (17). The increase of ozone leads to a relative risk of 1.02; $95 \% \mathrm{CI}=1.00-1.03$ for hospital admissions from cardio- vascular pathology (19). A study from Seoul in 1995-1999 confirms the same dependence after applying for description three statistical models (12). Similar results come from an investigation of 14 Spanish cities. The study of the association of ozone and daily mortality in Genoa, Italy, shows a mean increase of the total $(+4.0 \%)$ and cardio-vascular $(+7.2 \%)$ mortality one day after the increase of ozone levels by $50 \mu \mathrm{g} / \mathrm{m}^{3}$.

We find a more pronounced effect in summer (May to October). The highest correlational coefficients we establish in March (0.713) when the levels of pollution increase. A statistically significant synergic interaction of ozone and the temperature is described in relation to cardiac mortality $(16,17)$ - Fig. 1.

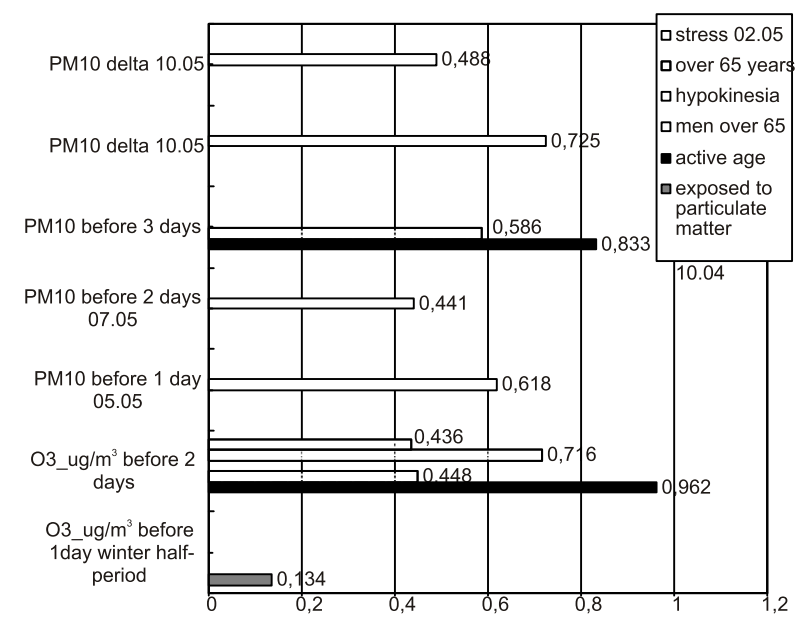

Fig. 1. Reliable correlational coefficients of daily frequency of AMI with the concentrations of ozone and particulate matter in the atmospheric air

The direct comparison of the two variational sequences concentrations of ozone in the atmospheric air and the frequency of hospital admissions from AMI not always allows to establish the presence of a relationship between them. A cause for that could be the accidental variations or the overlapping of alterations caused by seasonal, regional or social factors, which deforms the investigated correlation. For those reasons to establish the relationship between the ozone levels and diseases we apply methods, which allow for reduction of the information 'noise' and give a better picture of the wanted relations (3).

The method overlapping of time periods is a convenient and adequate means for discovering relationships when analysing a combination of phenomena for a long period of time (3). Its application at a zero day with over-the-limit values of ozone pollution proves the two-day duration of the effect on coronary circulation. The maximal frequency of AMI in persons working overtime and in conditions of hypokinesia is reached two days after the over-the-limit concentrations respectively of $0.18 \pm 0.2$ to $0.50 \pm 0.3$ and from $1 \pm 0.3$ to $1.4 \pm 0.4$ - Fig. 2 .

Through the application of the method of grouping the results we establish a reliable increase of the mean daily frequency of hospital admissions of persons who worked overtime from $0.08 \pm 0.03$ on the days with ozone concen- 
tration to $15.165 \mu \mathrm{g} / \mathrm{m}^{3}$ to $0.16 \pm 0.03 \mu \mathrm{g} / \mathrm{m}^{3}$ on days with ozone pollution of 15.165 to $60.765 \mu \mathrm{g} / \mathrm{m}^{3}(\mathrm{p}<0.05)$. In the next group of days with increased pollution above $60.765 \mu \mathrm{g} / \mathrm{m}^{3}$ the frequency of AMI in the same professional group continues to increase although the dynamics is statistically unreliable. Similar dynamics are established also for infarctions in persons working under strain of the thermoregulation, under stress and in drivers.

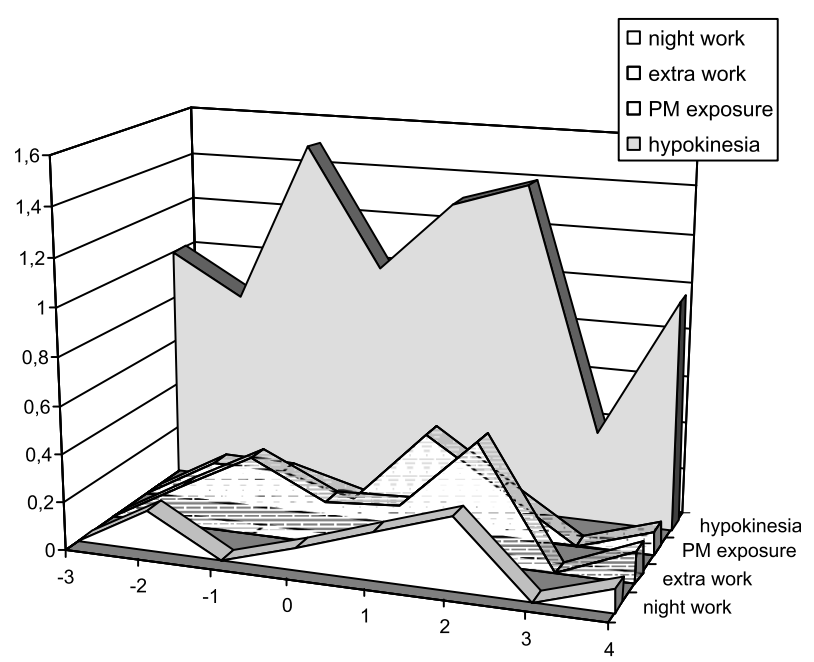

Fig. 2. Method of overlapping of time periods with a zero day on a day with over-the-limit concentrations of ozone

A pronounced seasonal dynamics of $\mathrm{PM}$ with higher values of the pollutant is established during the winter period. The annual dynamics defined on the basis of the mean monthly concentrations shows increased concentrations from November to February during automatic sampling and from September to March during manual sampling.

As to the ratio of PM10 concentrations, $\mu \mathrm{g} / \mathrm{m}^{3}$ to those of $\mathrm{NO}_{2}, \mu \mathrm{g} / \mathrm{m}^{3}$, a statistically significant difference is also established between summer and winter half-year in the values of the automatic point of sampling. This parameter shows a higher average value during the cold period when people heat their homes $(0.37 \pm 0.062$ against 0.00023 $\pm 0.000 \mathrm{p}<0.001$ ). It is proven that during this period the main source of particulate matter in inhabited areas is the burning of wood and coal, and in summer it is transport.

Zeka et al report of an alteration in the relationship between PM10 and cardiovascular hospital admissions due to differences in the ratios of the atmospheric constituents in the various cities (18). They also find important discrepancies in the relative share of primary particulate matter released by the transport, which are accepted to be the most toxic ones (13). There is described stronger influence on mortality from PM10 in cities with low ratio of PM10 to nitrogen dioxide in the gas composite, in towns with high average daily temperatures, low average relative humidity, low mortality and high relative share of susceptible persons over 65 years of age (11). Increased toxicity is found in more densely populated cities (14). The low ratio PM10/ $\mathrm{NO}_{2}$ should be interpreted as an indicator for a city with a high percentage of particulate matter as a result of the trans- port used, which also releases the prevalent part of $\mathrm{NO}_{2}$ in urbanised territories. That may be the explanation for the weaker than expected effects measured in 1995 in Eastern Europe (11), where the particulate matter from hard fuel burning is of a higher relative share. As a whole the particulate matter levels of atmospheric pollution in Central and Eastern Europe are high, with the most pronounced seasonal dynamics of PM10, which increases considerably during the heating season (10). It is possible that the negative cardiologic effect is also intensified due to the combined action of the meteorological parameters (6). The different toxicity of particulate matter is due to its different content as well (9) - Fig. 2.

Results show that there are registered hospital admissions from AMI in $76.9 \%$ of the days with increase of the PM10 concentration of $5 \mu \mathrm{g} / \mathrm{m}^{3}$ and in only $56.6 \%$ of the days without increase of dust $(p<0.05)$, the more intensive pollution of air with PM10 and the more sudden changes in the levels lead to similar cardiologic effects.

In the days with excess of threshold concentrations of general particulate matter in the atmospheric air, a higher mean frequency of the number of AMI is observed among workers exposed to some of the risk factors of the work environment like night labour and overtime, production noise, overheating microclimate and nervous and psychological strain. The mean daily frequency of AMI in persons with low physical activity at the workplace is reliably higher in the days with increased PM10 concentrations with 10 and more $\mu \mathrm{g} / \mathrm{m}^{3}$ (1.44 0.24) against the other days of the period $(0.890 .07 \mathrm{p}<0.05)$.

The observed by us different sex and age susceptibility to particulate matter with aerodynamic size less than $10 \mu \mathrm{g}$ is confirmed by the results of recent investigations (1). Seasonal differences in the health effect of PM established in other investigations are explained by the different chemical composition of the particles during the various months of the year. A main reason for those differences are the dynamics in the PM sources when during the different seasons dominate either the processes of burning fuels containing sulphur, or the exhaust gases from the cars, or sources releasing dust with silicon content (2).

The month-by-month examination of the effect of atmospheric pollution on the frequency of hospital admissions from AMI shows strong correlational subordination in October 2004. The influence of the respirable fraction of PM is described by significant correlational coefficients in Varna citizens in active age from both sexes (women 0.756 with the dynamics in the concentration and men 0.586 with the concentration from three days previously), carriers of conventional and occupational risk factors for AMI. Ozone is in a strong correlational relation with the frequency of AMI in active age ( 0.926 on day 2$)$ and again with those working in dangerous environment ( 0.419 with night labour, 0.420 in overheating microclimate, 0.451 in physical labour). The correlational subordinations with the dynamics of the particulate matter concentrations are positive for the period October 2004 to January 2005, and negative from April to June 2005. The seasonality, however, is not maintained during the cold months in the end of 2005. The 
dynamics of the ozone concentrations is in a positive correlational relation with the frequency of AMI in persons working under psycho-emotional strain in March (0.425) and negative in April (-0.421).

Most susceptible to particulate matter influence are the occupational groups with hypokinesia (movement of the body up to 2 hours or $<$ than $1 / 2$ of the working time) and low physical activity.

\section{CONCLUSIONS}

The seasonal subordinations described as well as the variability of the effect in combined models of interaction give reason to assume reciprocal influence of the effects on the coronary blood flow of ozone in its combined influence with the other atmospheric pollutants, as well as in its combination with the various meteorological parameters, and from there indirectly with the sun activity. At the same time those effects are determined also by the diverse individual susceptibility of the exposed persons.

Additional investigations are necessary on the effect of ozone and particulate matter separately or in combination. There exist many arguments and ambiguity in relation to the cumulative health risk under the influence of and super-positioning of the occupational risk factors in the multifactor genesis of AMI and the global cardio-vascular risk. The examination of the separate factors one at a time is not adequate or constructive. It is necessary to account for the reciprocal influence of the effects of the various factors both with each other and with the factors reflecting on the individual susceptibility of the exposed organism.

\section{REFERENCES}

1 Басмаджиева К., Л.Балабаева, Б.

Никифоров, Ив.Петров, Оценка на ефекта на атмосферното замърсяване в един район на цветната металургия, Хигиена $и$ здравеопазване, 1986, 6, 46-51;

2 Басмаджиева К., М.Аргирова, Б.Никифоров, С.Табакова, Й.Калпазанов, Оценка на връзката на атмосферното замърсяване и здравето на населението, Хигиена и здравеопазване, 1986, 4, 49-53 ;

3 Стефанов Б. Слънчевата активност, геомагнитното поле и човешкото здраве, София, 1989

4 Ballester F., Rodriguez P., Iniguez C., Saez M., Daponte A., Galan I., Taracido M., Arribas F., Bellido J., Cirarda F., Canada A., Air pollution and cardiovascular admissions association in Spain: results within the EMECAS project Journal of Epidemiology

5 Barnett A, Dobson A, McElduff P, Cold periods and coronary events: an analysis of populations worldwide, Journal of Epidemiology and Community Health 2005;59:551-557
6 Brunekreef B., Holgate S., Air pollution and health, The Lancet 2002/10/19,VL.360, IS 9341, 1233-1242

7 Chang Ch., Tsai Sh.,Ho S., Yang C., Air pollution and hospital admissions for cardiovascular disease in Taipei, Taiwan, Environmental Research 2005/5, VL.98, 1, 114-119

8 Fraigneau Y., Gonzalez M., Coppalle A., The influence of turbulence upon the chemical reaction of nitric oxide released from a ground source into ambient ozone, Atmospheric Environment 1996, VL.30, IS.9, $1467-1480$

9 Ghio AJ, Devlin RB. Inflammatory lung injury after bronchial instillation of air pollution particles. Am J Respir Crit Care Med 2001;164:704-8

10 Houthuijs D., Breugelmans O., Hoek G., Vaskovi E., Mihalikova E., Pastuszka J., Jirik V., Sachelarescu S., Lolova D., Meliefste K.,PM10 and PM2.5 concentrations in Central and Eastern Europe: results from the Cesar study, Atmospheric Environment, 2001/

11 Katsouyanni K, Touloumi G, Samoli E, et al. Confounding and effect modification in the short term effects of ambient particles on total mortality: results from 29 European cities within the APHEA2 project. Epidemiology 2001;12:521-31

12 Kim S., Lee J., Hong Y., Ahn K., Kim H., Determining the threshold effect of ozone on daily mortality: an analysis of ozone and mortality in Seoul, Korea, 1995-1999, Environmental Research, 2004/2, VL.94, IS.2, 113-119

13 Laden F, Neas LM, Dockery DW, et al. Association of fine particulate matter from different sources with daily mortality in six U.S. cities. Environ Health Perspect 2000;108:941-7

14 Maheswaran R, Haining R P, Brindley P, Law J, Pearson T, Fryers P R., Wise S and Campbell M J., Outdoor air pollution, mortality, and hospital admissions from coronary heart disease in Sheffield, UK: a small-area level ecological study, European Heart Journal online on September 15, 2005

15 Morgan G, Corbett S, Wlodarczyk J. Air pollution and hospital admissions in Sydney, Australia, 1990 to 1994. Am J Public Health 1998;88:1761-6

16 O'Neill M., Loomis D., Borja-Aburto V., Ozone, area social conditions, and mortality in Mexico City, Environmental Research 2004/3, VL 94, IS 3, 234-242

17 Parodi S., Vercelli M., Garrone E., Fontana V., Izzotti A.,Ozone air pollution and daily mortality in Genoa, Italy between 1993 and 1996,Public Health 2005/9 VL119, 9,844-850

18 Zeka A., Zanobetti A., Schwartz., Short term effects of particulate matter on cause specific mortality: effects of lags and modification by city characteristics, Occupational and Environmental Medicine 2005;62:718-725;

19 Zmirou D, Schwartz J, Saez M, et al. Time-series analysis of air pollution and cause-specific mortality. Epidemiology 1998;9:495-503 